\title{
Response of Maize-Hybrids Phenology Under high Plant Population Density in parts of Northern Guinea Savanna of Nigeria
}

\author{
Abubakar, A.W. ${ }^{1 *}$ Mohammad, U². Dangora, I. I ${ }^{3}$. \\ 1,3. Department of Biological Sciences, \\ Federal University Dutse, \\ P.M.B, 7156 Jigawa - Nigeria. \\ 2.Department of Biology, \\ Kano University of Science and Technology, \\ Wudil, Nigeria \\ E-mail: aisha.wada@fud.edu.ng
}

\begin{abstract}
Plant distribution in the field, as affected by plant density, has been one area that has received a great deal of attention over the last several decades. Population density, whether directly on the plant or indirectly on biotic factors associated with plant density is one of the most important factors in determining physiological attributes of a crop. Maize grain yield has a parabolic response to stand density that maximizes yield, which is widely known by the crop managers, physiologists and breeders; together with the concept that this optimum stand density varies with the environment. Development of breeding populations and hybrids with improved tolerance to high plant densities should be an important part of maize breeding programs. A field experiment was therefore conducted during 2015 and 2016 rainy season at Tudun Wada, Kano and Shika, Zaria in the Northern Guinea savanna of Nigeria in order to assess the phenological components of maize-hybrids at high plant population density. The experiment consisted of two plant populations of 53,333 plantha-1 and 88,888 plantsha-1 as main plot and eight recently developed drought-tolerant maize hybrids: M0826-7, M0926-8, M1026-10, M1026-13, M1124-4, M1124-10, M1227-12 and M1227-14 and two widely cultivated commercial hybrids as controls (Oba-98 and Oba super-1) as sub-plots laid out in a randomized split-plot design and replicated three times. Maize-hybrids responded to high plant population density in the two locations. Increasing plant population significantly decreased the phenology of maize-hybrids, which showed better adaptation of hybrids to high plant population density. Hybrids showed shorter days to maturity and shorter anthesis-silking interval. Maizehybrids performed better at Zaria than at Tudun Wada because rainfall was higher and better distributed in this location. However recent hybrids were more tolerant to high plant population than the commercial hybrids, therefore the recently released maize-hybrids were more adapted to biotic stress.
\end{abstract}

Keywords: Biotic stress, Growth, Phenology, Plant population density and Maize-hybrids. 


\section{INTRODUCTION}

Maize is an important crop for food and security, and the most consumed grain crop in Nigeria (Abubakar et al., 2017). Population density, whether directly on the plant or indirectly on biotic factors associated with plant density is one of the most important factors in determining grain yield and other agronomic attributes of a crop (Sangoi, 2001). Adjusting planting density is an important tool to optimize crop growth and the time required for canopy closure, as well as to achieve maximum biomass and grain yield (Kamara et al., 2006; Liu et al., 2008).

Crop cultivars respond differently to high plant density because of the differences in growth habit. Low plant density may lead to low grain yield because of little plasticity in leaf area of maize per plant and the limited capacity of maize plants to develop new reproductive structures in response to an increase in available resources per plant. On the other hand, extremely high plant density decreases availability of resources per plant in the period surrounding silking, that lead to marked fall in yield per plant (Sarlangue et al., 2007).

Plant density influences maize grain yield, kernel number, dry matter production, and aboveground dry matter allocation to the female reproductive sink, due to the competitive effects on both vegetative and reproductive development ( $\mathrm{Li}$ et al., 2015). Due to increasing introduction of drought tolerant genotypes into the savannas of West Africa, there is need to conduct further studies that are fundamental to identify the contribution of physiological, phenological and allometric traits to the putative improvement of modern-hybrids tolerance to high plant population densities (Abubakar et al., 2017).

A deeper understanding of the physiological determinants of maize response to high plant population may play a pivotal role to reach a greater yield plateau by revealing ways to achieve a better resource use and capture in the next decades. The study was therefore conducted to determine the phenological responses of maize-hybrids under high plant population (Abubakar et al., 2019).

\section{MATERIALS AND METHOD}

\section{Study area}

The experiment was conducted in 2015 and 2016 at two locations, Shika Zaria $\left(11^{\circ} 11^{\prime} \mathrm{N}\right.$ and $7^{0} 38^{\prime}$ E) and Tudun Wada $\left(11^{0} 11^{\prime} \mathrm{N}, 8^{0} 24^{\prime}\right.$ E) in the Northern Guinea Savanna.

\section{Procedures}

The experiment consisted of two plant population levels $\left(88,888\right.$, and 53,333 plantsha $\left.^{-1}\right)$ at $15 \mathrm{~cm}$ and $25 \mathrm{~cm}$ intra row spacing, as main plot and ten maize-hybrids as the sub-plot. Eight hybrids were (M0826-7, M0926-8, M1026-10, M1026-13, M1124-4, M1124- 10, M1227-12, and M1227-14) and two widely cultivated maize hybrids (Oba-98 and Oba super-1). In both years, the trials were laid out in a split plot design with three replications. Each plot size measured $3 \mathrm{~m} \times 5 \mathrm{~m}\left(15 \mathrm{~m}^{2}\right)$ consisting of 4 rows of $0.75 \mathrm{~m}$ apart and $5 \mathrm{~m}$ in length, while the net plot size measured $1.5 \mathrm{~m} \times 5 \mathrm{~m}\left(7.5 \mathrm{~m}^{2}\right)$. Alley way of $0.75 \mathrm{~m}$ between plots and $2 \mathrm{~m}$ between replications giving a total area of $1848.75 \mathrm{~m}^{2}$ per replication and $5981.25 \mathrm{~m}^{2}$ for the gross experimental area. Soil samples from both locations (Shika, Zaria and Tudun Wada) were collected at $0-15 \mathrm{~cm}$ and $15-30 \mathrm{~cm}$ depths prior to nitrogen application/planting and these were analyzed for physico-chemical properties; texture, available $\mathrm{P}$, total $\mathrm{N}, \mathrm{pH}$, organic carbon and exchangeable bases. Data on rainfall was utilized in the two locations for the purpose of this study. The land was ploughed and ridged with work bulls mounted with 
plough. The ridges were made $0.75 \mathrm{~m}$ apart and the plots were then laid out as per the number of treatment. Four seeds were planted per hole and thinned to 2 plants per stand. The first dose of nitrogen at the rate of 15 and $60 \mathrm{Kg} \mathrm{N} /$ ha was applied at 1WAS (weeks after sowing), using NPK 15:15:15. Nitrogen through urea granules (46\%) was applied at 4 WAS using band application. After planting, the area was sprayed with pre-emergence herbicide Gramoxone (1:1-dimethyl-4, 4-bipyrisdinum dichloride) Syngenta Crop protection AG, Switzerland at the rate of $276 \mathrm{~g}$ a.i/liter and 2 liters/ha. Weeding was done at 3 WAS, using a hoe. At 6 WAS, weeding was done by hand pulling method. Pests and diseases attacks were treated using lamdacyhalothrine $25 \mathrm{EC}$ at the rate of 1 liter/ha which was applied immediately after planting using a knapsack sprayer. Harvesting was carried out when the cob reached maturity, from the net plot i.e the two inner most middle rows in the plots. This was determined using Weather Stations device (2000 Series, Spectrum Technologies, USA). Data were collected from the two middle rows and a distance of two stands at the ends of each middle row was allowed to serve as borders. Observations were made and data was collected for phenological parameters. The data collected were subjected to analysis of variance (ANOVA) using the split-plot model and correlation analysis. Significant means were separated using the Fisher's protected least significant difference at $5 \%$ level of probability.

Data were collected based on the following parameters:

Number of days to $50 \%$ tasseling: Days to tasseling (anthesis date) was calculated as the number of days from planting to when $50 \%$ of the plants shed pollen.

Number of Days to 50\% Silking: Days to silking (silking date) was calculated as the number of days from planting to when $50 \%$ of the plants extrude silks.

Anthesis-silking interval (ASI): Anthesis-silking interval was calculated as the difference between days to anthesis and days to silking.

Number of Days to $95 \%$ Maturity: Number of days from planting to when $95 \%$ of the plants in the net plot reached physiological maturity (turn brown) was taken and recorded.

\section{Results}

Days to 50\% Flowering: Table 1 shows the days to flowering of maize as affected by plant population, maize-hybrids and their interaction. Longer days to flowering were significantly recorded in 2015 (62.00) than in 2016 (60.00) at Tudun Wada. There were no significant differences between years at Zaria. Plant population did not significantly affect the days to flowering of maize hybrids at both locations. Maize hybrids significantly differ in their days to flowering. Hybrids M1026-13 and Obasuper-1 had significantly longer days to flowering $(63.00,62.00)$ that were similar with other hybrids except with hybrids M0926-8, M1026-10, M1124-10, M1124-4 and M1227-12, shorter days to flowering (58.00) was recorded with hybrid M1124-4 at Tudun Wada. At Zaria, hybrid M1026-13 also took longer days to flowering (63.00) that was similar with other hybrids except with hybrids M0926-8, M102610, M1124-4, M1227-12 and Oba 98, which showed shorter days to flowering. Hybrid M11244 showed shortest days to flowering (60.00).

Days to 50\% Silking: Data on table 1 shows the days to silking of maize as affected by plant population, maize hybrids and their interaction. Days to silking were not significantly different in 2015 and 2016. Plant population did not significantly affect the days to silking of maize-hybrids at both locations. Maize hybrids significantly differ in their silking date. Hybrid Oba-Super-1 was observed to have delayed silking date (66.00) but similar with hybrid M1026-13 (65.00) at Tudun Wada. At Zaria, hybrid M1026-13 significantly showed 
delayed silking (65.00) but similar with hybrids M0826-7, M1124-10, M1227-14, and Oba super-1.

Anthesis-Silking Interval (ASI): Results on table 1 shows the anthesis-silking interval of maize as affected by plant population, maize hybrids and their interaction. Hybrids grown in 2016 produced ASI that was higher $(4.00,3.00)$ than that of $2015(2.00,1.00)$ at both Tudun Wada and Zaria. Plant population significantly affected ASI of the maize-hybrids. Plant population of 53,333 plants ha-1 showed higher ASI (3.00) when compared with that of 88,888 plants ha-1 $(2.00)$ at Tudun Wada. However at Zaria, plant population of 88,888 plantsha $^{-1}$ showed higher (2.00) ASI when compared with that of 53,333 plantsha-1 (1.00). Maize hybrids did not significantly differ in ASI at Tudun Wada. At Zaria, hybrid Oba-98 had significantly higher ASI (3.00) than the other hybrids.

Days to 95\% Maturity: Days to maturity as shown in table 1 were delayed in 2016 (98.00) than in 2015 (90.00) at Zaria but not significantly different at Tudun Wada. Days to maturity were significantly longer with plant population of 53,333 plants ha-1 ${ }^{-1}(106.00)$ when compared with plant population of 88,888 plants ha-1 $(105.00)$ at TudunWada. Maize-hybrids did not significantly differ in their days to maturity at both Tudun Wada and Zaria.

Table 1: Effect of plant population on growth and maturity of maize-hybrids during rainy season in Tudun Wada and Zaria

\begin{tabular}{|c|c|c|c|c|c|c|c|c|}
\hline \multirow{2}{*}{$\begin{array}{l}\text { Treatments } \\
\text { Year }\end{array}$} & \multicolumn{5}{|c|}{ Tudun Wada } & \multicolumn{3}{|c|}{$\underline{\text { Zaria }}$} \\
\hline & $\begin{array}{l}\text { Days to } \\
\text { flowering }\end{array}$ & $\begin{array}{l}\text { Days } \\
\text { to } \\
\text { Silking }\end{array}$ & $\begin{array}{l}\text { Anthesis } \\
\text { Silking }\end{array}$ & $\begin{array}{l}\text { Days to } \\
\text { Maturity }\end{array}$ & $\begin{array}{l}\text { Days to } \\
\text { flowering }\end{array}$ & $\begin{array}{l}\text { Days to } \\
\text { Silking }\end{array}$ & $\begin{array}{l}\text { Anthesis } \\
\text { Silking }\end{array}$ & $\begin{array}{l}\text { Days to } \\
\text { Maturity }\end{array}$ \\
\hline 2015 & $62.00^{a}$ & 64.00 & $2.00^{\mathrm{b}}$ & $110.00^{a}$ & 61.00 & 62.00 & $1.00^{\mathrm{b}}$ & $90.00^{\mathrm{b}}$ \\
\hline 2016 & $60.00^{\mathrm{b}}$ & 64.00 & $4.00^{\mathrm{a}}$ & $101.18^{b}$ & 61.00 & 64.00 & $3.00^{\mathrm{a}}$ & $98.00^{a}$ \\
\hline SED & 0.603 & 0.694 & 0.254 & 0.377 & 0.664 & 0.763 & 0.370 & 0.149 \\
\hline \multicolumn{9}{|c|}{ Population ha-1 } \\
\hline 53,333 & 61.00 & 64.00 & $3.00^{a}$ & 106.00a & 61.00 & 63.00 & $1.00^{\mathrm{b}}$ & 101.00 \\
\hline 88,888 & 61.00 & 64.00 & $2.00^{\mathrm{b}}$ & $105.00^{\mathrm{b}}$ & 62.00 & 63.00 & $2.00^{\mathrm{a}}$ & 98.00 \\
\hline SED & 0.476 & 0.504 & 0.223 & 0.281 & 0.277 & 0.421 & 0.185 & 0.224 \\
\hline \multicolumn{9}{|l|}{ Hybrid } \\
\hline M0826-7 & $61.00^{a b}$ & $64.00 \mathrm{bcd}$ & 2.00 & 105.00 & $62.00^{\mathrm{abc}}$ & $63.00^{\mathrm{abc}}$ & $1.00^{\mathrm{b}}$ & 100.00 \\
\hline M0926-8 & 59.00de & 63.00 de & 4.00 & 105.92 & $61.00 \mathrm{~cd}$ & $63.00 c$ & $2.00^{b}$ & 100.00 \\
\hline M1026-10 & 60.00 cde & 63.00 cde & 3.00 & 105.83 & $61.00^{\mathrm{cd}}$ & $62.00^{c}$ & $1.00^{\mathrm{b}}$ & 99.00 \\
\hline M1026-13 & $62.00^{a}$ & $65.00^{\mathrm{ab}}$ & 3.00 & 105.83 & $63.00^{\mathrm{a}}$ & $65.00^{a}$ & $2.00^{b}$ & 98.00 \\
\hline M1124-10 & $60.00^{\mathrm{bcd}}$ & 63.00cde & 3.00 & 106.58 & $62.00^{\mathrm{a}-\mathrm{d}}$ & $63.00^{\mathrm{abc}}$ & $1.00^{\mathrm{b}}$ & 100.00 \\
\hline M1124-4 & $58.00 \mathrm{e}$ & $62.00 \mathrm{e}$ & 4.00 & 106.08 & $60.00^{d}$ & $62.00^{c}$ & $2.00^{b}$ & 99.00 \\
\hline M1227-12 & 60.00de & 63.00cde & 3.00 & 106.33 & $61.00 \mathrm{bcd}$ & $63.00 \mathrm{abc}$ & $2.00^{b}$ & 99.00 \\
\hline M1227-14 & $62.00^{a b}$ & $64.00^{\mathrm{bcd}}$ & 2.00 & 106.42 & $62.00^{a b c}$ & $62.00^{b c}$ & $0.00^{b}$ & 105.00 \\
\hline Oba - 98 & $61.00 \mathrm{abc}$ & $65.00^{b c}$ & 4.00 & 105.17 & $61.00 \mathrm{~cd}$ & $64.00^{c}$ & $3.00^{a}$ & 106.00 \\
\hline Oba-super -1 & $63.00^{a}$ & $66.00^{a}$ & 3.00 & 106.25 & $63.00^{\mathrm{ab}}$ & $66.00^{\mathrm{ab}}$ & $3.00^{\mathrm{b}}$ & 106.00 \\
\hline SED & 0.823 & 2.245 & 0.567 & 0.455 & 0.692 & 0.683 & 0.489 & 0.315 \\
\hline \multicolumn{9}{|l|}{ Interaction } \\
\hline $\mathrm{Y} * \mathrm{P}$ & NS & NS & $*$ & * & NS & NS & NS & NS \\
\hline $\mathrm{Y} * \mathrm{H}$ & NS & NS & NS & NS & * & * & NS & NS \\
\hline $\mathrm{P} * \mathrm{H}$ & NS & NS & NS & NS & NS & NS & * & NS \\
\hline $\mathrm{Y} * \mathrm{P} * \mathrm{H}$ & NS & NS & NS & NS & NS & NS & NS & NS \\
\hline
\end{tabular}




\section{DISCUSSION}

The results clearly indicated that, successive increase in plant population density from 53,333 plants ha-1 to 88,888 plants ha $^{-1}$ had marked influences on the phenological parameters of maize-hybrids. The phenological parameters of the crop were extremely sensitive to the high plant population density during growth period. Maize-hybrids took longer days to flower with low plant population and shorter days to flower with high plant population at both locations $(58.00,63.00)$ as shown in table 1 . Days to flowering significantly differ among maize-hybrids.

The shorter days to silking demonstrated the adaptation of maize-hybrids under high plant population density, which was more pronounced in the modern hybrids at dense stands. This is in line with the work of Duvick and Cooper (2004) who speculated that modern corn hybrids are characterised by high production per unit area under high plant population, owing to morphological and phenological adaptations such as early silking, short anthesis to silking interval (ASI), few barren stalks, and prolificacy.

The significant decrease in ASI (2.00-3.00) with increase in plant population from 53,333 to 88,888 plants ha $^{-1}$ might be due to better adaptation of maize-hybrids under high plant population. The shorter ASI among the hybrids was reported by Kamara et al. (2006); loss of synchrony was less pronounced in the modern hybrids at dense stands. Bello et al. (2012) also confirmed that genotypes with reduced ASI would allow for better fertilization and good cob fill.

The significant increase in days to maturity with optimum population (53,333 plants ha-1) and decrease in days to maturity with high population $\left(88,888\right.$ plants $\left.^{-1} \mathrm{a}^{-1}\right)$ might be due to the fact that hybrids mature earlier under high plant population. This is in line with the work of Begna et al. (1997) who reported that maize hybrids mature earlier and tolerate higher population densities better than the current available hybrids. Similarly, Paszkiewicz and Butzen (2005) reported that hybrids with less than 100 CRM maturity perform best at higher populations.

Hybrids responded differently to plant population, which might be due to increased plant population showing that recent hybrids were more tolerant than older hybrids. The differential response to plant density in maize cultivars have also been reported by Xue et al. (2002). Similarly, Kamara et al. (2006) reported that recent hybrids were better able to withstand environmental stress and in line with the work of Hernandez et al. (2014) who postulated that hybrids differ in their optimum stand density for similar environment and greater crowding tolerance of modern genotypes allow using higher stand densities when compared with older ones. In contrary, Jason et al. (2013) pointed out that hybrids responded similarly to increased plant densities. 


\section{CONCLUSION}

The study indicated that the recently developed maize-hybrids responded better to high plant population density of 88,888 plants ha-1. Phenological parameters of the hybrids were generally shorter in Zaria than in Tudun Wada. High plant population showed decrease in phenological responses, which is an indication of early maturity. Interaction studies also showed that maize-hybrids responded differently to the high plant population of 88,888 plantsha ${ }^{1}$. Therefore, recently developed maize-hybrids showed better adaptation to biotic stress.

\section{RECOMMENDATION}

For expected early maturity, Hybrid M0826-7 can be recommended to farmers at Tudun Wada while hybrid M1026-13 can be recommended to farmers at Zaria. Screening exercise in response to biotic and abiotic stresses should be carried out prior to intensive cultivation of the crop

\section{REFERENCES}

Abubakar, A. W., and Manga, A.A. (2017). Effect of Plant Population on the Growth of Hybrid-Maize (Zea Mays L.) in The Northern Guinea Savanna of Nigeria, International Journal of Advances in Chemical Engineering \& Biological Sciences, (IJACEBS) 4(1): 134-141.

Abubakar, A.W., Dangora, I. I., Sadiq, S. B., Sunday, E., Tofa, A. I., (2019). Phenological Assessment of Maize-Hybrids under low nitrogen levels in parts of Northern Guinea Savanna of Nigeria. Dutse Journal of Pure and Applied Sciences. DUJOPAS 5(1a): 6877.

Begna, S.H., Hamilton, R.I., Dwyer, L.M., Stewart, D.W., and Smith, D.L., (1997). Effects of Plant Population Density on the Yield and Yield Components of Leafy ReducedStature Maize in Short season Areas. Journal of Agronomy and Crop Science, 178:103110.

Bello, M.S., Ige, S.A., Azzez, M. A., Afolabi, M.S., Abdulmalik, S.Y., and Mahamood, J. (2012) Heritability and Genetic Advance for Grain Yield and its component characters in maize. International journal of plant research, 2(15):138-145.

Duvick D.N., Smith, J., Cooper, M. (2004). Long-term selection in a commercial hybrid maize breeding program.In: Janick J (eds.) Plant Breeding Reviews, John Wiley and Sons New York, 109-151.

Hernandez, F., Amelong, A., and Borras, L. (2014). Genotypic Differences Among Argentinean Maize Hybrids in Yield Response to Stand Density. Agronomy Journal, 106:2316-2324.

Jason, A., Roth, Ignacio, A., Ciampitti and Tony, J. Vyn. ( 2013). Physiological Evaluation of Recent Drought -Tolerant Maize Hybrids at Varying Stress Levels Agronomy Journal 105: 1129- 1141. SLE:

Kamara, A.Y., Menkir, A., Kureh, I., Lucky O.O., and Ekeleme, F. (2006). Performance of old and new maize hybrids grown at high plant densities in the tropical Guinea savanna. Communications in Biometry and Crop Science, 1:41-48.

Li, J., Xie, R.Z., Wang, K.R., Ming, B., Guo, Y.Q., Zhang, G.Q., and Li, S.K. (2015). Variations in Maize Dry Matter, Harvest Index, and Grain Yield with Plant Density. Agronomy Journal, 107:829-830. 
Liu, X.B., Jin, J., Wang, G.H., and S.J. Herbert. (2008). Soybean yield physiology and development of high-yielding practices in Northeast China. Field Crops Res. 105:157171.

Paszkiewicz, S., and Butzen, S. (2005). Corn Hybrid Response to Plant population pioneer Decade study Crop Insights 6(11):1-9.

Sangoi, L. (2001). Maize plant arrangement: analysis of the state of the art. Ciência Rural, 31:1075-1084.

Sarlangue, T., Andrade, F.H., Calvino, P.A. and Purcellc, L.C. (2007). Why do maize hybrids respond differently to variations in plant density. Agronomy Journal, 99:984-991.

Xue, J., Liang, Z., Ma. G., Lu, H., and Ren, J., (2002). Population physiological indices on density tolerance of maize in different plant types. Ying Yong Sheng Tai Xue BAO, 13(1): 55-59. 